Andrey Babanov (iD https://orcid.org/0000-0002-2093-4965

Petersburski Uniwersytet Państwowy

e-mail: a.babanov@spbu.ru

Ilia Afanasev (iD https://orcid.org/0000-0002-9169-6829

Petersburski Uniwersytet Państwowy

e-mail: szrnamerg@gmail.com

\title{
Opis struktur syntaktycznych we wczesnych pracach Zenona Klemensiewicza i Noama Chomskiego
}

\section{Streszczenie}

Artykuł jest poświęcony konfrontacji wczesnych prac Z. Klemensiewicza (głównie Sktadnia opisowa wspótczesnej polszczyzny kulturalnej, 1937) i N. Chomskiego (głównie Syntactic Structures, 1957). Autorzy tych dzieł wywodzą się z różnych nurtów lingwistycznych - pierwszy z lingwistyki strukturalnej, drugi z lingwistyki generatywnej. Mimo to w ich ideach da się zauważyć istotne zbieżności. Chociaż nie ma podstaw, by uważać dzieła Klemensiewicza za bezpośrednią inspirację dla Chomskiego, wygląda jednak na całkiem uzasadnione twierdzenie, że różne szkoły myśli lingwistycznej nieraz były dosłownie o krok od zapoczątkowania paradygmatu generatywnego.

Słowa kluczowe: studia nad polszczyzną, lingwistyka generatywna, N. Chomsky, Z. Klemensiewicz, lingwistyka strukturalna

\section{Wstęp}

Połowa XX wieku dla językoznawstwa okazała się czasem zmiany paradygmatu naukowego, polegającej na przejściu od lingwistyki strukturalnej ku lingwistyce generatywnej. Lingwistyka strukturalna pierwszej połowy XX wieku koncentrowała się na opisie 
formalnej organizacji języka i jej uzewnętrznienia w formach językowych, natomiast lingwistyka generatywna interesowała się przede wszystkim tym, jak język jest zorganizowany wewnętrznie i jak ta organizacja uzewnętrznia się w posługiwaniu się językiem i w jego przyswajaniu przez osobę mówiącą.

Przejście to dokonywało się powoli w ciągu dłuższego okresu, na którego początku badano konkretne języki - z tych to badań zrodziła się lingwistyka per se, przechodząc powoli ku rozważaniom nad językiem jako takim. Dzieło N. Chomskiego Syntactic Structures właściwie okazało się świadectwem, że nowy paradygmat już powstał.

Zanim jednak Syntactic Structures zostały napisane i wydane, ukazywały się inne prace, w których badacze na materiale różnych języków przystępowali do analizowania mniej więcej podobnych zjawisk, a mianowicie modeli odtwarzanych przez użytkownika języka podczas generowania wypowiedzi. Za jednego z takich prekursorów N. Chomskiego można uznać Z. Klemensiewicza, którego kapitalne synchroniczne opracowania różnych działów gramatyki języka polskiego ukazały się pod koniec lat trzydziestych XX wieku.

W centrum uwagi niniejszego artykułu są cechy podejścia Z. Klemensiewicza do zjawisk gramatycznych w ogóle i do składni języka polskiego w szczególności, zapowiadające sposób opisu syntaktycznego, zrealizowany przez N. Chomskiego - przynajmniej w wersji występującej w jego wcześniejszych dziełach.

Przeanalizujmy zatem główne tezy Syntactic Structures oraz opis gramatyki języka polskiego zawarty w pracach Klemensiewicza z lat 1937 i 1939. Badanie będzie przebiegało w następujący sposób: najpierw opiszemy główne tezy, które Chomsky wprowadza w Syntactic Structures, a które stały się kamieniem węgielnym dla lingwistyki generatywnej, zanim ukazał się The Minimalist Program; następnie scharakteryzujemy metodę opisu gramatycznego Klemensiewicza zastosowaną w jego głównych dziełach sprzed II wojny światowej. Za takie dzieła uważamy Składnię opisowa współczesnej polszczyzny kulturalnej (1937) oraz Gramatykę współczesnej polszczyzny kulturalnej w zarysie (1939). Przedstawimy kontekst naukowy tych książek, podstawowe punkty ich treści oraz wpływ na dalszy rozwój teorii lingwistycznej. Poza tym, w celu zaprezentowania szerszego kontekstu dzieł Chomskiego, a zwłaszcza Klemensiewicza, przywołamy niektóre dzieła innych językoznawców.

Przedmiotem badania w pierwszej kolejności będzie rozumienie pojęcia struktury w składni przez Klemensiewicza i Chomskiego, wykrycie punktów, w których ich koncepcje wykazują różnice czy odwrotnie - w których okazują się zbieżne. Dodatkowo za istotny należy uznać sposób wizualizacji tych struktur w dziełach wymienionych autorów, ponieważ poniekąd umożliwia on wgląd w ich pojmowanie i opis struktur składniowych.

\section{Autorzy}

Chomsky i Klemensiewicz to postacie tej samej rangi, mimo że zasięg oddziaływania ich teorii jest różny. Dokładne biografie językoznawców ani szczegółowe opisy ewolucji ich poglądów lingwistycznych nie zostały jeszcze napisane. Jak dotąd zarówno w przypadku 
Chomskiego, jak i Klemensiewicza o wiele łatwiej znaleźć cytaty z ich dzieł niż teksty im poświęcone ${ }^{1}$.

Ranga Chomskiego jako lingwisty nie budzi żadnych kontrowersji, jego dzieła, zwłaszcza Syntactic Structures (Chomsky, 1957) i The Minimalist Program (Chomsky, 1995), należą do kanonu prac, które zadecydowały o dzisiejszym kształcie językoznawstwa. Istnieje także szereg ważnych publikacji Chomskiego z późniejszego okresu, podsumowujących dorobek poznawczy ludzkości z pogranicza biologii człowieka i językoznawstwa, z których najpóźniejszą jest Why Only Us. Language and Evolution (Berwik, Chomsky, 2016). Chomsky inspirował nie tylko lingwistów, ale też naukowców eksplorujących inne dziedziny, na przykład nauki komputerowe. Jedno z najbardziej znaczących dzieł w tej dziedzinie, The Art of Computer Programming D. Knutha (1968), jako źródło inspiracji podaje Syntactic Structures Chomskiego.

Postać Klemensiewicza, choć z pewnością nie przewyższa sławą wymienionego wcześniej lingwisty, to zdecydowanie jest imponująca. Znaczenie dzieł tego badacza dla językoznawstwa polskiego jest niewątpliwie większe niż znaczenie dzieł Chomskiego dla językoznawstwa ogólnego. Klemensiewicz był jednym z badaczy, którzy w latach trzydziestych XX wieku zainicjowali synchronistyczny opis gramatyki współczesnego języka polskiego. Właśnie do tego rodzącego się nurtu należą jego pierwsze syntezy: Składnia opisowa współczesnej polszczyzny kulturalnej (Klemensiewicz, 1937) oraz Gramatyka współczesnej polszczyzny kulturalnej w zarysie (Klemensiewicz, 1939). Książki te zawierają opis realnie funkcjonującej polszczyzny, wykonany z niespotykaną dotąd dokładnością i systematycznością, a ponadto prezentują podejście do opisu zjawisk gramatycznych, które na tamte czasy było nowością w odniesieniu nie tylko do języka polskiego. Później Klemensiewicz współpracował przy tworzeniu cenionej pozycji, jaką jest Gramatyka historyczna języka polskiego (Klemensiewicz, Lehr-Spławiński, Urbańczyk, 1955). Był także autorem (niestety niedokończonej z powodu śmierci językoznawcy) nie mniej ważnej, trzytomowej Historii języka polskiego (Klemensiewicz, 1981-1972)2, w następnych latach kilkakrotnie wznawianej w wersji zawierającej wszystkie trzy tomy łącznie (Klemensiewicz, 1974). Dzięki tym dziełom jego postać wśród badaczy historii staje się tak samo znacząca jak wśród badaczy zajmujących się opisem gramatyki języka polskiego.

Zatem Chomsky i Klemensiewicz to wybitni badacze o różnorakich zainteresowaniach naukowych, obejmujących zarówno ścisłą synchronię, jak i różne (nie te same) aspekty diachronii. Nowatorskim opisem języka w równej mierze unowocześnili oni swoją dyscyplinę badawczą. By zrozumieć, dlaczego skala tych unowocześnień okazała się różna, należy przeanalizować ich dzieła nieco dokładniej.

\footnotetext{
${ }^{1}$ Biogram Z. Klemensiewicza jest zamieszczony w: Śródka, Szczawiński, 1984. Biografia N. Chomskiego doczekała się opracowania monograficznego: zob. McGilvray, 2014.

2 Tom 1: Doba staropolska, tom 2: Doba średniopolska, tom 3: Doba nowopolska.
} 


\section{Klemensiewicz i Chomsky - podobieństwa}

Mimo niewątpliwych różnic, których można spodziewać się w przypadku dzieł Chomskiego i Klemensiewicza, da się zauważyć istotne cechy wspólne ich prac.

Dobrze znane jest zdecydowane dążenie Chomskiego do unowocześnienia lingwistyki, przeformatowania jej, a może nawet stworzenia od podstaw na nowo. Żąda on, żeby nowe podejście w dziedzinie badania języka było ,rigorously stating a proposed theory and applying it strictly to linguistic material with no attempt to avoid unacceptable conclusions"3 (Chomsky, 1957: 6). Postulat ten u Klemensiewicza nie występuje expressis verbis, w swoich pracach raczej proponuje on rozwiązania prezentujące to, co Chomsky stwierdza i deklaruje. Formalistyczne podejście w połączeniu z wymogiem ścisłości wyraźnie widać w takim na przykład sformułowaniu: „W badaniach syntaktycznych trzeba przede wszystkim ustalić, co właśnie stanowi przedmiot składni” (Klemensiewicz, 1937: 1).

Obaj autorzy podejmują próbę klasyfikacji struktur syntaktycznych, przy czym Chomsky stara się dokonać wglądu w sposoby transformowania wypowiedzeń: „how sentences are constructed in different languages"4 (Chomsky, 1957: 11), Klemensiewicz zaś klasyfikuje efekty tych transformacji w jednym konkretnym języku (polskim): „Prosta i potoczna obserwacja pozwala wyodrębnić w języku trzy utwory różnego rzędu" (Klemensiewicz, 1937: 1).

Między autorami jest niewątpliwa jednomyślność, kiedy stwierdzają niejasność istoty obiektu, oznaczanego jako „wypowiedzenie”. Klemensiewicz pisze: „Czym jest wypowiedzenie - oto podstawowe zagadnienie składni” (Klemensiewicz, 1937: 1). Chomsky ma zamiar badać to pojęcie, stawiając sprawę tak: „On what basis, do we actually go about separating grammatical sequences from ungrammatical sequences?"5 (Chomsky, 1957: 14). A więc obaj autorzy zdecydowanie odczuwają potrzebę nie tylko gruntownej zmiany całego paradygmatu, ale też nowego zdefiniowania podstawowego pojęcia wypowiedzenia (zdania).

Zagadnienie ostatnie w kolejności, ale nie pod względem znaczenia - to ich sposób konceptualizacji wypowiedzenia (zdania) jako struktury. W Składni... Klemensiewicza znajdujemy wykres (rys. 1).

\footnotetext{
${ }^{3}$,rygorystycznie trzymała się zaproponowanej teorii i stosowała ją bezpośrednio do materiału językowego, nie próbując unikać niechcianych wniosków" - tłum. A.B.

4 „w jaki sposób wypowiedzenia są budowane w różnych językach” - tłum. A.B.

5 „co dla nas właściwie jest podstawą przy odróżnieniu gramatycznych wypowiedzeń od niegramatycznych sekwencji?" - tłum. A.B.
} 


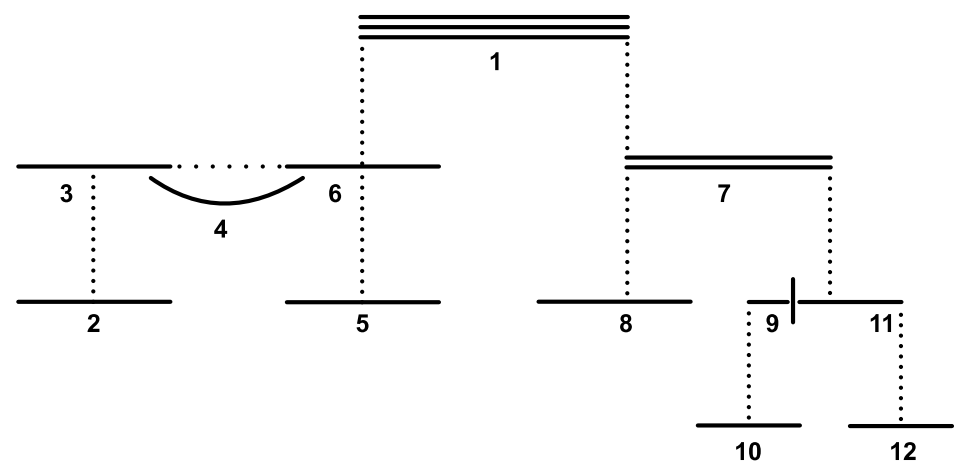

Rysunek 1. Przykład schematu używanego przez Klemensiewicza do wizualizacji koncepcji wypowiedzenia

Źródło: Klemensiewicz, 1937: 94.

Jest to jeden z pierwszych przykładów gramatyki zależności. Porównywalny jest do bardzo wyraźnych i sformalizowanych opracowań, takich jak Dependency Syntax: Theory and Practice (zob. Mel'čuk, 1987: 13-14), i odnotować podobieństwa w sposobach przedstawiania struktur składniowych. Chomsky idzie znacznie dalej w swojej zrewidowanej teorii standardowej, tworząc wraz z innymi badaczami gramatykę składników, jak to określa Andrew Radford (1981).

Najbardziej uderzającym podobieństwem między rozwiązaniami Chomskiego i Klemensiewicza wydaje się zamiar wyłuszczenia ograniczonej liczby struktur z nieograniczonego zbioru wypowiedzeń, próba zrozumienia podstawowej struktury badanego języka. Być może ktoś zaoponuje, twierdząc, że Klemensiewicz robi to raczej podświadomie, natomiast Chomsky deklaruje to jako cel, ale jest tak dlatego, że paradygmat sensu lato Klemensiewicza poprzedza paradygmat Chomskiego. Najważniejsza różnica tkwi jednak w rodzaju języka, który występuje jako obiekt tych badań.

\section{Chomsky i Klemensiewicz - różnice}

Pomimo podobieństw podstawowych założeń między podejściami Chomskiego i Klemensiewicza da się odnotować sporo rozbieżności.

Przede wszystkim trzeba pamiętać, że dzieła Klemensiewicza i Chomskiego powstawały w różnych czasach i w ramach różnych szkół lingwistycznych. Klemensiewicz zaczynał swoje badania przed II wojną światową, a kontynuował w powojennej Polsce. Chomsky działał w powojennych Stanach Zjednoczonych. Nie należy się tym zbyt mocno sugerować, ale nie można też pomijać tego faktu, analizując badania omawianych autorów.

W badaniach Klemensiewicza widoczna jest wyraźna tendencja do psychologizmu, a czasem nawet do metody introspektywnej (Klemensiewicz, 1937: 6), a to zbliża go nie z Chomskim, lecz z jego oponentami - zarówno tymi, których tezy Chomsky obala 
w Syntactic Structures, jak i tymi, którzy poddawali krytyce teorię Chomskiego. Trzeba jednak powiedzieć, że argumenty, które przytacza Klemensiewicz w swoich dziełach, w większym stopniu, aczkolwiek w dość naiwny sposób, zapowiadają przyszłe badania kognitywistów niż prace behawiorystów jemu współczesnych. Chomsky zaś, jeżeli chodzi o stosunek do psychologii, zwłaszcza w późniejszych pracach stwierdza korelację, lecz nie powiązanie przyczynowo-skutkowe pomiędzy psychologią a językiem (Berwik, Chomsky, 2016).

Klemensiewicz analizuje tylko fakty języka polskiego. Chomsky natomiast, chociaż był krytykowany za anglocentryzm swoich dzieł, może właśnie dla uniknięcia takiej krytyki stara się być jak najbardziej uniwersalistyczny. Przedmiotem jego zainteresowania jest „the general nature of Language”6 (Chomsky, 1957: 14). Klemensiewicz tymczasem świadomie realizuje zamiar napisania gramatyki języka polskiego, na co w sposób zupełnie jednoznaczny wskazują tytuły jego dzieł. A więc pod tym względem ich dzieła znajdują się jakby w lustrzanej opozycji. Chomsky postuluje uniwersalistyczne twierdzenia, mocno ograniczając przy tym materiał, z którego korzysta, Klemensiewicz zaś wyprowadza niektóre wnioski ogólniejszej natury z dość bogatego materiału, ale ograniczonego pod względem języka, z którego materiał ten pochodzi.

Prace Klemensiewicza, mające ogromne znaczenie dla lingwistyki polskiej, wyróżniające się wielką ścisłością i szczegółowością opisu, osadzone są w ramach paradygmatu lingwistyki strukturalnej. Pisząc je, badacz najwyraźniej zmierzał do tego, żeby sformułować ograniczony zestaw reguł, które pozwalałyby generować nieograniczoną liczbę wypowiedzeń, i opisać te reguły w sposób mocno sformalizowany (Klemensiewicz, 1937: 197). Pozostało to jednak w dużej mierze zamiarem, gdyż opisane zostały dość specyficzne reguły dotyczące jednego konkretnego języka. Chomsky natomiast proponuje, by użyć jego sposobu do opisu Języka, a nie wyłącznie jednego z języków (Chomsky, 1957: 50).

Trzeba podkreślić, że nie zamierzamy przypisywać merytorycznej wyższości jednego dzieła nad innym tylko z powodu przynależności do tego czy innego paradygmatu. Należy o tym pamiętać przy porównawczej analizie dzieła Chomskiego, które rzeczywiście zapoczątkowało nowy nurt w lingwistyce, i dzieł Klemensiewicza z lat przedwojennych, które nie tylko reprezentują bardzo wysoki poziom badania w ramach lingwistyki strukturalnej, ale także okazują się zwiastunem lingwistyki generatywnej. Nie poprzednikiem czy prekursorem, co można by powiedzieć o wielu pracach powstałych przed Syntactic Structures, lecz właśnie zwiastunem.

\section{Wnioski}

Jako jeden z wniosków z powyższej analizy nasuwa się stwierdzenie, że mimo podobieństw aparatu teoretycznego w pracach Klemensiewicza i Chomskiego ich teorie w swojej treści istotnie się różnią. Różnią się także losy tych teorii po ukazaniu się dzieł,

\footnotetext{
${ }^{6}$ „ogólna przyroda Języka” - tłum. A.B.
} 
w których zostały przedstawione, bo stały się podstawowymi pozycjami dla dwu różnych szkół myśli lingwistycznej.

Klemensiewicz, wykonując swoje badania w konwencji lingwistyki strukturalnej, wnosi istotny wkład do dorobku językoznawstwa polskiego, a jednocześnie próbuje odpowiedzieć na pytania natury ogólniejszej, na przykład czym właściwie jest wypowiedzenie (zdanie).

Chomsky z kolei tworzył nowy paradygmat nauki lingwistycznej, nie stawiając przed sobą celów w zakresie badań nad jakimś konkretnym językiem, i próbował odpowiedzieć na pytania, które nurtowały lingwistów od wielu dziesięcioleci.

Jak już stwierdzono, nie wiąże prac Klemensiewicza i Chomskiego relacja bezpośredniej inspiracji i kontynuacji, chociaż może gdyby dzieliła ich mniejsza odległość geograficzna, byłoby to możliwe. A to dlatego, że prace Klemensiewicza zawierały w sobie Zeitgeist późniejszego okresu i w pewnym sensie rzeczywiście kształtowały to, co dopiero miało nastąpić, a mianowicie - epokę lingwistyki generatywnej, która ogłosiła swoje zasady w latach pięćdziesiątych XX wieku.

\section{Bibliografia}

Berwik R.C., Chomsky N. (2016), Why Only Us. Language and Evolution, Cambridge-London. Chomsky N. (1957), Syntactic Structures, Berlin.

Chomsky N. (1995), The Minimalist Program, Cambridge.

Klemensiewicz Z. (1937), Składnia opisowa współczesnej polszczyzny kulturalnej, Kraków.

Klemensiewicz Z. (1939), Gramatyka współczesnej polszczyzny kulturalnej w zarysie, Wrocław-Warszawa.

Klemensiewicz Z. (1961-1972), Historia języka polskiego, Warszawa.

Klemensiewicz Z., Lehr-Spławiński T., Urbańczyk S. (1955), Gramatyka historyczna języka polskiego, Warszawa.

Knuth D. (1968), The Art of Computer Programming. Vol. 1, Boston.

McGilvray J. (2014), Chomsky: Language, Mind, and Politics, Cambridge.

Mel'čuk I.A. (1987), Dependency Syntax: Theory and Practice, Albany.

Radford A. (1981), Transformational Syntax: A student's Guide to Chomsky's Extended Standard Theory, Cambridge.

Śródka A., Szczawiński P. (1984), Biogramy uczonych polskich. Część I: Nauki społeczne, zeszyt 2: $K-O$, Wrocław. 


\section{Abstract \\ Description of syntactic structures in the early works of Zenon Klemensiewicz and Noam Chomsky}

The article focuses on the early works of Z. Klemensiewicz (mostly Składnia opisowa współczesnej polszczyzny kulturalnej, 1937), and N. Chomsky (mainly Syntactic Structures, 1957). These authors come from different linguistic paradigms: structural linguistics, and generative linguistics, respectively. Despite that, their ideas have strong similarities, and although there is no reason to consider Klemensiewicz's work as a direct inspiration for Chomsky, it seems quite reasonable to argue that different schools of linguistic thought were at times literally one step away from pioneering the generative paradigm.

Keywords: Polish language studies, generative linguistics, N. Chomsky, Z. Klemensiewicz, structural linguistics 